\title{
Exploring the Strategic Role of Infrastructural Choices on Manufacturing Performance: Evidence from Kenya Sugar Sector
}

\author{
Odollo, Okoth Lawrence $^{1^{*}} \quad$ Ochieng, Omolo Victor ${ }^{2}$ \\ 1.Jomo Kenyatta University of Agriculture and Technology, Kenya \\ 2.The Cooperative University of Kenya, Kenya
}

\begin{abstract}
Technological developments in the sugar manufacturing sector require that the managers of these manufacturing firms devise strategies and make astute infrastructural choices in order to ensure survival, growth and improve manufacturing performance of the firm. This requires manufacturing firms to devise manufacturing technological advancements, frequent innovations, as well as rapid developments in their infrastructural capacities. The purpose of the study was to explore the strategic role of infrastructural choices in supporting manufacturing performance of sugar manufacturing firms in Kenya. Specifically, the study sought to: assess the effect of work force on performance, examine the effect of policies on performance, to explore the effect of communication on performance, and to determine the effect of innovation on performance of sugar manufacturing firms in Kenya. Anchored on Strategic and Routine Based theories, the study adopted both descriptive and experimental research designs anchored on realism ontology, and used both quantitative and qualitative approach. The unit of analysis was sugar manufacturing plant. The respondents were sought through both purposive and simple random sampling strategies, yielding a sample of 165 respondents. Structured questionnaires and interview schedule were used to collect primary data. Data was processed both descriptively and inferentially using Microsoft Excel 2010 and SPSS version 21. EFA, correlation analysis and regression analysis, were equally used, while qualitative data analysis was done through expert judgment, scenario mapping and critical thinking. The overall study results revealed that infrastructural choices have significant effect on manufacturing performance.
\end{abstract}

Keywords: Infrastructural choices, Decision areas, manufacturing performance.

DOI: $10.7176 / \mathrm{EJBM} / 11-28-10$

Publication date:October $31^{\text {st }} 2019$

\section{Introduction}

The Kenya's sugar sector is facing stiff competition from low-cost sugar manufacturing firms from established global economies which competes away the industry profits. Consequently, "competing on cost" (price leadership) strategy is becoming economically untenable. It is therefore, becoming increasingly evident that the expansion of world sugar production into the foreseeable future is unlikely (Ketema, 2015; Tyler, 2013). These technological developments hence require that the managers of manufacturing firms devise strategies and make astute operational decisions and choices in order to ensure survival, and improve performance of the firm. In this regard, managers must craft and implement appropriate strategies at all levels. The current global economic crunch consequently has a spiral effect leading to closure of several sugar mills. Globally, there has been a structural deficit in sugar production, and as Czarnikow (2013) outlines, the projected world sugar production deficit has been steadily rising from 8.51 Metric Tons Raw Value (MTRV) in 2012 to 9.29 MTRV in 2015. To bridge this gap, it requires efficient manufacturing systems to achieve efficiency and effectiveness (Czarnikow, 2013). Unfortunately, this production dream has remained a mirage. To bridge the production deficit, the manufacturing systems and capacities ought to be interconnected and incorporated into the corporate strategy to achieve its strategic objectives.

In Kenya, the manufacturing sector accounts for eleven percent (11\%) of gross domestic product (GDP) (Mbalwa, Kombo, Chepkoech, Koech and Shavulimo, 2014). However, the importance of sugar and its economic viability in Kenya is under threat from various factors within and without the sugar industry (Mbalwa et al., 2014). Specifically, the poor performance by Kenya sugar sector has led several sugar firms be closed or be put under receivership, while the government has to bail out some of them. Currently, the government is toying with the idea of privatizing most of the state - owned sugar firms in order to salvage them and protect the livelihood (Czarnikow, 2013; Tyler, 2013). A study by Gachene, Kathumo, Gicheru, and Kariuki (2012) identifies low productivity at factory level leading to low sugar yields and capacity under-utilization, among other challenges. Ultimately, Tyler (2013) intones that these sugar manufacturing plants need to be big and to operate with high efficiency in order to process cane at low cost. This requires that these sugar manufacturing firms should employ support services that aid their performance and diversify their strategies to attain the required production scales and standards. In this regard, the sugar firms need to refocus their strategies, and infrastructural choices strategies offer manufacturing firms an alternative and structured approach to decision making in facilitating an economic production to improve their competitiveness, survival and growth and performance to achieve the set objectives.

Initially, researchers argued that different manufacturing firms explored different environmental factors 
affecting firms' strategies and manufacturing performance as key competitive drivers (Boyer and Lewis, 2002). However, other scholars (Schroeder, 2011), later found that industry structure and or attractiveness have insignificant influence on a firm's ability to improve its performance. In view of this, this study explored the internal sources of competitive advantage embedded on connectedness and communication as well as competence of employees. This was an effort to help manufacturing organizations analyze their internal capabilities and competences that contribute to better performance, and to offer firms a strategic direction.

\subsection{Statement of the Research Problem}

The sugar manufacturing sector accounts for eleven percent (11\%) of the GDP (Mbalwa, et al., 2014). However, this is considered low compared to most middle-income countries. To achieve strategic production objective, Tyler (2013) intones that the sugar manufacturing factories need to be big and to operate with high efficiency. Gachene et al. (2012) identify low productivity at factory level leading to low sugar yields and capacity under-utilization, highlighting high level of manufacturing inefficiencies. Even though most of sugar manufacturing firms in Kenya are large, their efficiencies are however in doubt. The poor performance by Kenya sugar sector has led several sugar firms be closed or be put under receivership, while the government has to bail out some of them. Currently, the government is toying with the idea of privatizing most of the state - owned sugar firms in order to salvage them and protect the livelihood (Czarnikow, 2013; Tyler, 2013). This requires that these sugar manufacturing firms should employ support services that aid their performance and diversify their strategies to attain the required production scales and standards.

In this regard, the sugar firms need to refocus their strategies, and infrastructural choices strategies offer manufacturing firms an alternative and structured approach to decision making in facilitating an economic production to improve their competitiveness, survival and growth and performance to achieve the set objectives. Unfortunately, the identification and application of infrastructural choices into manufacturing strategies is still insufficient, and it is difficult today to find sugar manufacturing firms that use their infrastructural choices' functions as a strategic manufacturing weapon, yet it is a core functional level strategy that helps manufacturing firms gain competitive advantage (Ketema, 2015; Gognon, 2009). The current study thus postulated that the cardinal problem resides in the identification and application of infrastructural choices, as a strategic strategy.

\section{Literature review}

\subsection{Theoretical foundations}

A theory is a systematic explanation of the relationship among phenomena (Ngumi, 2013). In essence, theories provide a generalized explanation to an occurrence, and thus offer the researcher a framework for the study. This study was hinged on both the Strategic Contingency Theory as well as Institutional Theory. Their arguments and general implications to infrastructural choices and manufacturing performance were explored. This study proposed an integrated theoretical approach rather than a single theoretical perspective to facilitate clear understanding of the effect of operations strategy on the performance of sugar manufacturing firms. Such an approach is supported by Suzana (2014) who calls for multiple theoretical perspectives.

Core to every manufacturing process is the question that describes the nature of the linkages between patterns of manufacturing choices performance. The strategic contingency theory of organizations offers a theoretical lens for this purpose (Helkiö, 2008). An outline by Ketema (2015) suggests the need to integrate the manufacturing patterns and capabilities that contribute to superior performance. While disputing the assumption that there is "one best way" to manage manufacturing firms, Hayes and Pisano (2005) contend that different production systems (the composite of decisions in a number of key decision areas) have different operating characteristics and therefore, rather than adopting an industry-standard production system, the task for a company's manufacturing function is to construct a production system that, through a series of interrelated and internally consistent decisions, reflects strategies inherent in its specific competitive situation (Ketema, 2015). When applied correctly, the theory allows for a maximum performance that can be achieved by a unit contingent on a set of interrelated decisions, that boil down to choices in plant design (structural) and plant operations infrastructural factors. The application of the theory thus will help the sugar manufacturing firm adopt and survive through various strategies, thereby maximizing its manufacturing performance (Helkiö, 2008).

Institutional theory constitutes the hypothesized infrastructures through which organizational structure factors exert their influence (Amenta and Ramsey, 2010). In addition, Ketema (2015) argues that since institutions provide the rules and regulations of the game that governs the structure and organizational interactions within decision areas of the production system, the role of institutional environment is becoming important especially in the contemporary management of organizations. In addition, Cai et al. (2010) contends that institutional theory explains the existence of the boundaries and their internal organizational structures. Given that the sugar sector environment in Kenya is highly volatile and unpredictable as a result of insufficient formal market - support institutions, Dung (2012) argues that a firms strategy can be better be predicted through the use of institutional based view, followed by resource based view (Brown and Squire, 2016; Dung, 2012; Moller et al., 2003). This 
(2014) further intones that it is easy to change aspects of operations infrastructure quickly than the structure.

Based on the existing quality improvement methodologies open to a manufacturing firm seeking to improve the quality of process outputs, Gong (2013) would reason that the sugar manufacturing firm needs to identify and remove the causes of production errors and minimizing variability in manufacturing processes, and hence lay infrastructure for future development of low cost and high quality competencies. This underscores Slack and Lewis' (2012) intention by concluding that in some investment decisions appropriate infrastructure is needed to support the main operations facility and can be as significant as, if not more than, the investment in the operation itself. In essence, a set of reporting relationships can be embedded within an organizational structure which may reflect different structural and infrastructural process.

A study by Ketema (2015) analyzed drivers of manufacturing performance in medium and large-scale firms in Ethiopia. Data was gathered at plant level from 197 MLSF by use of a quant - emphasis mixed method approach along with cross - sectional survey design, and the collected data was analyzed qualitatively. The hypothesized relationships were analyzed by Structural equation modeling (SEM). Importance to the current study is that infrastructural choices account for $74.6 \%$ variation in manufacturing performance. In addition, the study concluded that infrastructural manufacturing decisions have a significant influence on manufacturing performance when a firm seeks to achieve quality and delivery priorities.

Based on a single case study in a metallurgical company, Sciuto and Filho (2013) explored the relationship between manufacturing strategy and the lean manufacturing system. Primary data was collected by both semi structured interviews and direct observation of two production managers, while secondary data was collected through in-depth document analysis. The analysis revealed that infrastructural areas greatly and positively influence the implementation of lean manufacturing system, which leveraged various process improvements, mainly administrative, aimed at increasing productivity, development of robust performance indicators, and improved interface with suppliers.

In addition, a survey conducted by Luger et al. (2013) among 500 manufacturing firms in the United Kingdom (UK) based on a two - step methodology, revealed that infrastructure ranked third as a component of competitiveness. The study further showed that infrastructural choices are a key component of a firm's both competiveness and attractiveness which is critical for policy concerns. Although the study ranked infrastructure third, the study however concluded that comparisons of importance of infrastructure to manufacturing competitiveness are difficult to make across firms because of differing demographics, industry mix, among others. The current study hence was based on the premise that as sugar manufacturing firms improve their infrastructural choices as a distinct strategy at functional areas, the operations performance improves as well. And it is on this premise that the study formulated the relevant null hypothesis stated as:

$H_{01}$ : $\quad$ There is no significant effect of infrastructural choices on the performance of sugar manufacturing firms in Kenya.

\subsubsection{Manufacturing Performance}

When it comes to metrics, an old adage has it that what gets measured gets done. Literature indicates that performance measurement provides the management with both means of control, and also supports for developing appropriate strategies to improve their performance (Söderbom, 2011). Manufacturing performance is the measurable aspect of an organization's process by quantifying the process for efficiency and effectiveness of an action taken (Malonza, 2014). Even though traditional measures have been in use since 14th century, manufacturing firms have continuously incorporated "best practices" in their operations (Kasie and Belay, 2013). However, with the changes in technology and high production techniques, their usefulness have been questioned, especially related to manufacturing strategies. Fueling the doubt further is Hallgren (2010) who acknowledges that it is difficult to fairly assess the performance of a manufacturing firm due to external factors beyond the scope of manufacturing operations. This calls for multiple combinations of metric indicators needed to ensure that business objectives are being met.

In view of the above, the current study hence used an Operations Performance Measurement Model (OPMM), as a strategic management system performance measure, whose indicators are efficiency and effectiveness (Hallgren, 2010). Imperative to acknowledge is the fact that every dimension, to some extent, is vital for all operations, and as Hallgren notes, which of the performance indicator is the most important one is subject to competitive positioning of the manufacturing firm within the industry. The use of OPMM is advanced by Kasie and Belay (2013) and further note that firms which measure their performance using a combination of financial and non-financial measures achieve better performance. Kasie and Belay (2013) further argue that non-financial measures have not been integrated with each other, as well as with strategic objectives of sugar manufacturing firms to offer a more pragmatic view of measuring manufacturing performance of these sugar manufacturing firms. All performance dimensions can be measured either from an internal as well as external perspective. Further, Kasie and Belay (2013) advance that the internal perspective measurement represents measures which are useful for the internal monitoring and management of the manufacturing process. 
This study adopted internal measurements to manage manufacturing process, which is hypothesized to positively contribute to manufacturing performance. While sugar firms are more likely to adopt a combination of the above cited measurement indicators, Littlefield and Shah (2008) are of the opinion that the adoption of these indicators can never take place in a vacuum, and the key to improved performance lies in simultaneous use of multiple performance dimensions. This is in agreement with a study by Gong (2013) which advances that to realize improved manufacturing performance, it is vital for a sugar manufacturing firm to formulate a strategy that seeks a fit between business strategy in different functional units within the firm and performance.

\section{Research methodology}

Research methodology is a conceptual structure within which a research is conducted, and it outlines the blue print for collecting, measuring, and analyzing data (Kothari, 2010). Research methodology is hence a detailed procedure to be followed to realize the research objectives.

\subsection{Research Philosophy}

As a theoretical framework underpinning the research process, and providing a guiding structure and a range of acceptable research tools to aid the research seeking answers to study the hypotheses posited (Creswell, 2006), the study adopted post - positivism-based philosophy.

The methodology facilitated the assessment of process - oriented to explain the underlying causal tendencies (Abdulkareem, Adel, and Anchor, 2010). Moreover, the methodology was equally appropriate for the current study since it allowed situational information to be collected from their natural settings, with an objective of assessing the causative effect of operations strategy on the performance of sugar manufacturing firms in Kenya.

\subsection{Research Design}

Whereas Kothari (2010) defines research design as the arrangement of conditions for collection and analysis of data in a manner that aims to combine relevance to the research purpose with economy with procedure, Onen and Yuko (2009) avers that research design is the overall strategy for conducting the research, chosen to integrate different components of the study in a coherent and logical way, so as to minimize the chance of drawing incorrect causal inferences from the data set so collected and analyzed. In order to achieve the set objective, the current study adopted both descriptive survey and experimental research designs, and used both quantitative and qualitative methods.

Descriptive research design was used to diagnostically determine the frequency with which the study variable constructs occur, and further explored relationships between operations strategies and operations performance, to facilitate predictions, accompanied by narration of facts and characteristics as they were observed (Kothari, 2010; Kombo and Tromp, 2009). An experimental research design was employed in order to facilitate testing of the stated hypotheses and help explore the cause - effect relationships among the study variables that the study proposes (Kothari, 2010; Onen and Yuko, 2009).

\subsection{Target population and sample size}

For this study, the target population were the entire twelve (12) sugar manufacturing firms registered (table 3.1), and licensed by Kenya Sugar Board as at June 2015, which were equally the unit of analysis for the current study. The study used both purposive and simple random mixed sampling techniques to get the respondents sample size. The production managers $\left(n_{1}=12\right)$, operations supervisors $\left(n_{2}=35\right)$ and finance managers $\left(n_{3}=12\right)$ were purposively sampled. Besides conveniently sampling respondents, a sample of floor workers were drawn through a simple random technique by adopting a formula provided by Nassiuma (2000) thus:

$$
n=\frac{N c^{2}}{c^{2}+(N-1) e^{2}} \text {, where } \mathrm{n}=\text { Sample size, } \mathrm{N}=\text { Population, } \mathrm{c}=\text { covariance, while } \mathrm{e}=\text { standard error. }
$$

Nassiuma (2000) suggests a coefficient of variation in the range of $21 \% \leq \mathrm{C} \leq 30 \%$ and a standard error in the range $2 \% \leq \mathrm{e} \leq 5 \%$ is usually acceptable. Therefore, the current study proposed to use a coefficient variation of $21 \%$ and a standard error of $2 \%$. The lower limits for coefficient of variation and standard error were selected so as to ensure low variability for stability of sample data set, and to minimize the degree of error. The application of the formula to the category of floor workers gives a total sample size of 99 . Therefore, sample respondents per sugar manufacturing firm were obtained by proportionately apportioning a sample size to each firm, and then, respondents were randomly sampled. The overall sample size for the study was one hundred and sixty-five $\left(n_{1}+\right.$ $\left.n_{2}+n_{3}+n_{4}=165\right)$. However, figures were rounded up for statistical analysis. Collecting data from multiple respondents allowed for an assessment of inter-rater reliability, allows informants to address issues in their areas of expertise and/or scope, as well as reduces common method bias (Boyer and Lewis, 2012; Ketema, 2015).

\subsection{Data Collection Method and Instruments}

This study collected both primary and secondary data and utilized both quantitative and qualitative approaches. 
According to Coopers and Schindler (2013), it is critical to use both quantitative and qualitative data as one is insufficient on its own to capture all trends in a study. The study equally used external sources of data as a way to validate and supplement the primary data that was collected for analysis.

Primary data was collected by use of structured questionnaires, interview schedules, and document analysis. Structured questionnaire with fixed response alternatives followed a five - point Likert type scale were administered to operations supervisors as well as floor works, while interview schedule was administered to both the production and finance managers. The relevant documents of individual company were perused through to extract the relevant information to validate the information for the study (Kothari (2010; Onen and Yuko, 2009; Allen and Seaman, 2007).

\subsection{Pilot testing}

Prior to carrying out the actual research, piloting was done to ensure that the research tools developed for use in the research were suitable in their content, and that the respondents were able to interpret the questions in a manner intended by providing proxy data for a selection of a probability sample. The purpose of pilot study was to ensure that the study instruments measures what it was supposed to measure (Coopers and Schindler, 2013; Kothari, 2010). The researcher, therefore, was able to refine the data collection instruments accordingly.

The responses obtained from the pilot study were used to determine the validity and reliability of the questionnaire of which the relevant amendments were made to the questionnaire items before administering it to the actual study respondents.

From the pilot study reliability statistics as shown in table 3.1 revealed that all the infrastructural choices and performance measurement items met the minimum reliability threshold, hence was conclude that the instruments were sufficiently reliable for the study.

Table 3.3: Pilot study variable Reliability Statistics

\begin{tabular}{lllll}
\hline Piloted study variables & $\begin{array}{l}\text { Cronbach's } \\
\text { Alpha }\end{array}$ & $\begin{array}{l}\text { Cronbach's Alpha } \\
\text { Standardized Items }\end{array}$ & Based & on $\begin{array}{l}\text { N } \\
\text { Items }\end{array}$ \\
\hline Performance & .875 & .865 & 9 & 18 \\
Infrastructural Choices & .936 & .939 & & 9 \\
\hline
\end{tabular}

To ensure validity for the study, the questionnaire measurement items were guided by the conceptual framework constructs (figure 2.1) in order to measure infrastructural choices and manufacturing performance measurement items. Moreover, Ketema (2009) advises that to assure validity, the construct measures and their indicators be taken from several conceptual and empirical literatures, as the current study had done, evidenced from various cited sources. To attain content validity, the research instrument scales were built on the basis of prior literatures, which were validated in different empirical studies.

Moreover, the questionnaires were given to two research experts to evaluate the relevance of each item in the instruments to the study objectives. The content validity hence was determined using Content Validity Index (CVI). Mathematically, C.V.I was determined as thus:

$$
\text { C.V.I }=\frac{n_{3 / 4}}{N} \text {, }
$$

The C.V.I thus yield a minimum acceptable index of 0.8 (Onen and Yuko, 2009), and those questionnaire items that did not meet the criterion were either restructured or dropped from the questionnaire. The results were then used to fine - tune the questionnaire items to ensure that the instruments measured as accurately as possible the salient research characteristics that they were intended to measure (Kombo and Tromp, 2007). Consequently, the CVI index of the pilot study instrument yielded an index of 0.867 , which was considered sufficient.

\subsection{Data Processing and Analysis}

Collected data was processed and analyzed using IBM's SPSS software version 21.0 and, while Microsoft Excel 2010 was used to generate various means to facilitate generation of statistics inferentially. The SPSS database was designed based on the pre-coded questionnaires sub-themes. Results of data analysis were presented in frequency distribution tables in chapter four. The study generated both quantitative and qualitative data. Quantitative data collected was analyzed by use of both descriptive and inferential statistics to determine trends and to enable comparisons among the study variables in order to make deductions; interpretations; conclusions; and possible recommendations. For comparison purposes, the key variable factors were identified using confirmatory factor analysis. This helped in checking dimensionality of the scale. Using confirmatory factor analysis, the number of components to extract were determined using the Eigen values, which were expected to be greater than one (Fields, 2003). Factor loadings was set at 0.4 and used Principal Component Analysis (PCA) method to extract the factors.

Qualitative data collected was condensed by editing, paraphrasing, and summarized in order to derive meaning from it. Qualitative data collected was organized according themes and patterns of occurrence derived from the five objectives of the study, and were analysed using content analysis technique. The qualitative data responses through semi - structured interview schedule were analyzed through expert judgment, scenario mapping 
and critical thinking. This, according to Kosikoh (2014) involves reading through the questionnaires, developing codes, coding the data, and drawing connections amongst various discrete pieces of data. Quantitative values assigned to the structured questions were then keyed in the SPSS software data base to analyze, to identify patterns and emerging trends among the study variables, then was presented descriptively. The qualitative data analysed is so brief and was obtained from few production documents and additional comments given by both production and finance managers in the interview schedule.

\section{Research Findings and Discussions}

\subsection{Response rate}

Although the study had intended to collect data from a sample of 165 respondents, data was successfully obtained from 131 of them. This represents a response rate of 79.4 percent of the target population. A study by Boyer and Lewis (2002) found a return rate of 40.6 percent, while a study by Malaba, Ogolla, and Mburu (2014) had a return rate of 74.5 percent. Comparatively a return rate of 79.4 percent was considered good enough to validate the current study results, which surpasses the 10 percent of the total population as recommended by Mutunga, Minja, and Gachanja (2014) and Kothari (2010).

\subsection{Demographic Profile of Respondents}

The study explored the demographic data of the valid respondents by analyzing their experience and academic qualifications. To assess the level of work experience, the study required the respondent to indicate on a continuum how long they had worked in the organization. The study results are represented in table 4.1

Table 4.1: How long have you worked in this organization

\begin{tabular}{llccc}
\hline & Frequency & Percent & Cumulative Percent \\
\hline \multirow{4}{*}{ Valid } & Less than 1 year & 9 & 6.9 & 6.9 \\
& 1 - 5 years & 32 & 24.4 & 31.3 \\
& 6 - 10 years & 43 & 32.8 & 64.1 \\
& Over 10 years & 47 & 35.9 & 100.0 \\
& Total & 131 & 100.0 & \\
\hline
\end{tabular}

The study assumed that experience gained through extended working period injects high level and yet competencies necessary in carrying out ones duties (Abdulkareem, et al., 2010). The level of work experience as illustrated in table 4.2 indicates that 6.9 percent had worked in their current organization in less than a year, 24.4 percent had worked between one and five years, 32.8 percent had worked for between six and ten years, while 35.9 percent had worked for over ten years. This implies that an accumulation of 68.7 percent of the respondents were found to have gained the necessary competences embedded in skills, knowledge and experience as key to competitive advantage.

In the same vain, from the strategic perspective, the competencies gained through time are contingent of function, routines and processes in an organization. At one instance, the researcher came across one manager who confessed to have had a twenty (20) years' experience working with one of the firm, twelve of which in the same position. The manager indicated that he had mastered the routines "mentally" and needed no reminder of what to do and when to do it. This level of experience was assumed to have led to the development of critical path routines that contributed to the success of the system.

Table 4.2: For how long have you worked at the current position

\begin{tabular}{llccc}
\hline & Frequency & Valid Percent & Cumulative Percent \\
\hline \multirow{4}{*}{ Valid } & Less than 3 year & 23 & 17.6 & 17.6 \\
& 4 -6 years & 36 & 27.5 & 45.0 \\
& 7-9 years & 30 & 22.9 & 67.9 \\
& Above 10 years & 42 & 32.1 & 100.0 \\
& Total & 131 & 100.0 & \\
\hline
\end{tabular}

Table 4.2 determined the experience of respondents in their current position, of which, 17.6 percent of respondents had worked for less than three years, 27.5 percent had worked between four and six years, 22.9 percent had worked between seven and nine years, while the majority (32.1 percent) had worked at their current position. These study findings confirms argument by Katema (2015); Bhargava and Anbazhagan (2014), and Abdulkareem, et al., (2010) that respondents with a high working experience have the technical knowledge that assists in providing reliable data on the study problem under investigation. This indicates that on average, an accumulation of 93.1 percent had prerequisite experience and thus understood technical issues on the variables under study. In assessing the level of experience both at organizational level and the current position, these study findings are consistent with the Resource Based View theory which in this case, would view these intangible resources as specific to individual firms 


\subsection{Descriptive Statistics for manufacturing Performance measurement Items}

Frequencies, expressed as a percentage of the sample, were used to explain the number of times the respondents (dis)agreed with the hypothesized state. Descriptive statistics were generated for each performance construct and results were as shown in table 4.3.

Table 4.3: Descriptive statistics for Efficiency and Effectiveness items

\begin{tabular}{|c|c|c|c|c|c|c|c|c|}
\hline Efficiency Items & & SD & $\mathbf{D}$ & $\mathbf{N}$ & $\mathbf{A}$ & $\mathbf{S A}$ & Mean & $\begin{array}{l}\text { S. } \\
\text { D }\end{array}$ \\
\hline The process procedures improve efficiency & $(\%)$ & 0 & 1.5 & 0.8 & 67.9 & 29.8 & 4.26 & 0.55 \\
\hline $\begin{array}{l}\text { Employees productivity is much higher that the industry } \\
\text { average }\end{array}$ & $(\%)$ & 2.3 & 28.8 & 4.6 & 47.5 & 17.6 & 3.50 & 1.15 \\
\hline $\begin{array}{l}\text { The firm regularly improves internal operations } \\
\text { processes }\end{array}$ & $(\%)$ & 0 & 10.7 & 3.1 & 67.2 & 19.1 & 3.95 & 0.81 \\
\hline Key Performance Metrics are reviewed frequently & $(\%)$ & 0.8 & 13.7 & 3.1 & 59.5 & 22.1 & 3.89 & 0.93 \\
\hline $\begin{array}{l}\text { Impediments that hold up progress are resolved on time } \\
\text { Effectiveness Items }\end{array}$ & $(\%)$ & 3.8 & 20.6 & 3.1 & 54.2 & 18.3 & 3.63 & 1.12 \\
\hline $\begin{array}{l}\text { Scale of operation is sufficient to produce the required } \\
\text { volume }\end{array}$ & $(\%)$ & 0 & 20.6 & 0.8 & 55 & 23.7 & 3.82 & 1.02 \\
\hline $\begin{array}{l}\text { Operations maintain flexibility while increasing } \\
\text { accountability }\end{array}$ & $(\%)$ & 3.1 & 17.6 & 8.4 & 53.4 & 17.6 & 3.65 & 1.06 \\
\hline The activities are undertaken as scheduled & $(\%)$ & 3.1 & 19.8 & 3.1 & 51.1 & 22.9 & 3.71 & 1.12 \\
\hline Sugar products meet prescribed quality standards & $(\%)$ & 0 & 0 & 1.5 & 71.8 & 26.7 & 4.25 & 0.47 \\
\hline
\end{tabular}
Means: $1-1.8=\mathbf{S D}, 1.9-2.7=\mathbf{D}, 2.8-3.3=\mathbf{N}, 3.4-4.2=\mathrm{A}$, Above $4.2=\mathbf{S A}$

Key: $\boldsymbol{S D}=$ Strongly Disagree, $\boldsymbol{D}=$ Disagree, $\boldsymbol{N}=$ Neutral, $\boldsymbol{A}=$ Agree, $\boldsymbol{S} \boldsymbol{A}=$ Strongly Agree

The study sought to assess how best the presented study statements described the efficiency of the sugar manufacturing system. To assess the extent to which the production procedures improve efficiency, 97.7 percent generally agreed while 1.5 percent dissented. The item had a mean of 4.26 with standard deviation of 0.55 . To determine the productivity of employees', 65.1 percent generally agreed while 31.1 percent generally disagreed that employees are more productive than the industry average, with the item averaging at 3.50 and a standard deviation of 1.15 .

In addition, 86.3 percent generally agreed compared to 10.7 percent who disagreed that an individual firm regularly improves internal operations processes. The item had a mean response of 3.95 and a standard deviation of 0.81 . Moreover, 81.6 percent of the valid respondents generally agreed that Key Performance Metrics are reviewed frequently compare to 14.5 percent that dissented. The efficiency item had a mean response of 3.89 with a standard deviation of 0.93 . To assess whether the impediments that hold up progress are resolved on time, 72.5 percent of the valid respondents generally agreed compared to 24.4 percent that generally disagreed.

The study results revealed that all the efficiency indicators had a mean greater than 3.2, about which the respondents generally agreed and is an indication that the efficiency measurement items listed are of considerable importance (Abdulkareem et al., 2010). To assess how best the presented study statements described the effectiveness of the sugar manufacturing system, the study results equally revealed means of $3.82,3.65,3.71$, and 4.25, all of which are above 3.2. This further proves the respondents generally agreed that the effectiveness measurement items were of considerable importance.

\subsection{Exploratory Factor Analysis for Manufacturing Performance}

The validity of the model constructs was assessed by subjecting the variable item responses from the questionnaires to Exploratory Factor Analysis (EFA) to assess the extent to which the observed indicators represents an underlying latent construct fitted with the pre-specified theoretically driven model (Hair, Black, Babin, Anderson, and Tathan, 2005), and aid to identify the least number of factors which can account for the common variance of a set of variables.

The initial part of the factor extraction process was to determine the linear components within the data set (eigenvectors). All of the nine performance measurements items were subjected to the factor analysis. By use of Kaiser criterion, SPSS was used to retain components with Eigen values $\geq 1$. Consequently, only one component was extracted as presented in table 4.4 . 
Table 4.4: Total Variance of Manufacturing Performance items Explained

\begin{tabular}{|c|c|c|c|c|c|c|}
\hline \multirow[b]{2}{*}{ Component } & \multicolumn{3}{|c|}{ Initial Eigenvalues } & \multicolumn{3}{|c|}{ Extraction Sums of Squared Loadings } \\
\hline & Total & $\begin{array}{c}\% \text { of } \\
\text { Variance }\end{array}$ & Cumulative \% & Total & $\%$ of Variance & Cumulative $\%$ \\
\hline 1 & 2.242 & 74.743 & 74.743 & 2.242 & 74.743 & 74.743 \\
\hline 2 & .453 & 15.108 & 89.851 & & & \\
\hline 3 & .304 & 10.149 & 100.000 & & & \\
\hline
\end{tabular}

Extraction Method: Principal Component Analysis.

Presented in table 4.4 is a list of eigenvalues associated with the linear component (factor) upon extraction. Accumulatively, the extracted factor explained 74.743 percent of the total variance in the operations performance items. This implies that the system identified one factor structure with the relative importance. This underscores the assertion of Brown (2006) that it important to conduct a factor analysis in order to produce a solution with the best simple structure.

From the extracted factor is highly and positively related with "Activities are taken as scheduled" with a coefficient of 0.887 , followed by "Key performance metrics are reviewed frequently" $(0.877)$, and lastly "Regular improvement of internal operations" had a positive coefficient of 0.829 . From the extracted study items, the component extracted is mapped onto efficiency. This implies that efficiency was identified as the most preferred performance indicator by the study.

Table 4.5: Component Matrix ${ }^{\mathrm{a}}$ for Manufacturing Performance

\begin{tabular}{lc}
\hline & Component \\
\cline { 2 - 2 } Activities are taken as scheduled & Efficiency \\
Key performance metrics are reviewed frequently & .887 \\
Regular improvement of internal operations & .877 \\
\hline
\end{tabular}

Regular improvement of internal operations

Extraction Method: Principal Component Analysis.

a. 1 components extracted.

These results confirm a study by Malonza (2014) which sought to explore the contribution of manufacturing efficiency on operational performance of Mumias Sugar Company Limited. The study findings revealed that overally, the factory efficiency has a 50.9 percent emphasis $\left(\mathrm{R}^{2}=0.509\right)$ on operational performance and consequently, when amplified, led to a reduction of waste but improved quality in operations due to improved efficiencies and standardization of processes. The results further confirm assertion by Wamalwa et al. (2014) that factory efficiency determines factory production operations throughout the production period without interruptions, and as such, it is an important indicator to operational performance of a manufacturing industry. In addition, although a study by Raheman et al., (2010) revealed a small magnitude improvement of efficiency to large-scale manufacturing, its contribution was concluded to be important to performance. The above studies confirm assertion by several supervisors that core to their operations is efficiency, which was the main focus of their individual management achievements. This, according to the managers, had a direct bearing on the costs of operations and overall performance of the production section.

From the extracted communality matrix associated with efficiency measurement items, the average of the communalities is given by 0.748 . In order to validate construct validity of operations performance, the KMO of Sampling Adequacy and Bartlett's Test of Sphericity as a measure of sampling adequacy was conducted to determine appropriate items for analysis (Field, 2003), results of which is presented in table 4.16

Table 4.16 : KMO and Bartlett's Test for Performance items

Kaiser-Meyer-Olkin Measure of Sampling Adequacy.

Approx. Chi-Square

Bartlett's Test of Sphericity

df

Sig.

For adequacy, the KMO test statistic had an index of 0.710 which is greater than the conventional minimum probability value of 0.5 , implying that factor analysis is good and hence appropriate for the data set. Equally presented in table 4.6 is Bartlett's Test of Sphericity which contains an approximated Chi-square of 149.165, with an associated $\mathrm{p}$ - value lower than the conventional probability value of 0.05 (Hair et al., 2013; Williams et al., 2010; Field, 2003). It was hence concluded that the factor analysis was appropriate for assessing construct validity of the scale. Consequently, from the Bartlett's Test of Sphericity results, the study rejected the null hypothesis which means that the variables have a strong association.

4.5 Effect of Infrastructural Choices on Performance

All the workforce measurement items had a mean greater than 3.2 implying that the respondents generally agreed 
that the work - force is competent in their areas of responsibilities to take up their roles and duties in their respective areas of operations. In essence, this should lead to a superior performance, according to Zaim, Yasar, and Üna, (2013). However, the lowest mean was for the "the management facilitates employees' further training in areas of specialization" measurement item. This is an indication that although training important in developing employees' skills and competence, the management gives it a lower premium.

In assessing policies, the respondents were non-committal whether the management involves the workers while setting the policies, with a lower mean of 3.18 and a standard deviation of 1.03. It shows that the management leas adopt a participatory approach while setting targets. It could equally means that these competent employees prefer free hand in their areas of work.

Both communication and innovation measurement items had their means greater than 3.2, indicating that respondents generally agreed that the constructs are of considerable importance (Abdulkareem, et al., 2010) in determining infrastructural choices at the operations areas. This was confirmed with the fact that the management bases its practices on formal mechanisms while transferring the practices among various areas of work, with the measurement item had a mean of 3.72, standard deviation of 1.03 .

Table 4.33: Descriptive statistics for Infrastructural Choices measurement items

\begin{tabular}{|c|c|c|c|c|c|c|c|c|}
\hline Work - force measurement items & & SD & D & $\mathbf{N}$ & $\mathbf{A}$ & SA & Mean & S.D \\
\hline $\begin{array}{l}\text { The team is empowered to make decisions to meet its } \\
\text { goals }\end{array}$ & $\begin{array}{c}\text { Freq } \\
\%\end{array}$ & $\begin{array}{c}3 \\
2.3\end{array}$ & $\begin{array}{c}15 \\
11.5\end{array}$ & $\begin{array}{c}3 \\
2.3\end{array}$ & $\begin{array}{c}66 \\
50.4\end{array}$ & $\begin{array}{c}44 \\
33.6\end{array}$ & 4.02 & 1.02 \\
\hline $\begin{array}{l}\text { The team is prepared to take responsibilities that help } \\
\text { achieve its goals. }\end{array}$ & $\begin{array}{c}\text { Freq } \\
\%\end{array}$ & $\begin{array}{c}3 \\
2.3\end{array}$ & $\begin{array}{c}9 \\
6.9\end{array}$ & $\begin{array}{c}6 \\
4.6\end{array}$ & $\begin{array}{c}85 \\
64.9\end{array}$ & $\begin{array}{c}28 \\
21.4\end{array}$ & 3.96 & 0.86 \\
\hline $\begin{array}{l}\text { The workforce has the prerequisite competence } \\
\text { related to their tasks }\end{array}$ & $\begin{array}{c}\text { Freq } \\
\%\end{array}$ & $\begin{array}{l}0 \\
0\end{array}$ & $\begin{array}{c}18 \\
13.6\end{array}$ & $\begin{array}{c}6 \\
4.6\end{array}$ & $\begin{array}{c}61 \\
46.6\end{array}$ & $\begin{array}{c}46 \\
35.1\end{array}$ & 4.03 & 0.97 \\
\hline $\begin{array}{l}\text { The management facilitates employees' further } \\
\text { training in areas of specialization } \\
\text { Policies measurement items }\end{array}$ & $\begin{array}{c}\text { Freq } \\
\%\end{array}$ & $\begin{array}{l}13 \\
9.9\end{array}$ & $\begin{array}{c}17 \\
13.0\end{array}$ & $\begin{array}{c}6 \\
4.6\end{array}$ & $\begin{array}{c}80 \\
61.1\end{array}$ & $\begin{array}{c}15 \\
11.5\end{array}$ & 3.51 & 1.16 \\
\hline $\begin{array}{l}\text { The operations policies and procedures adopted help } \\
\text { to achieve the set objectives }\end{array}$ & $\begin{array}{c}\text { Freq } \\
\%\end{array}$ & $\begin{array}{l}0 \\
0\end{array}$ & $\begin{array}{c}4 \\
3.1\end{array}$ & $\begin{array}{l}12 \\
9.2\end{array}$ & $\begin{array}{c}77 \\
58.8\end{array}$ & $\begin{array}{c}38 \\
29.0\end{array}$ & 4.14 & 0.69 \\
\hline $\begin{array}{l}\text { The management involves workers while setting } \\
\text { policies }\end{array}$ & $\begin{array}{c}\text { Freq } \\
\%\end{array}$ & $\begin{array}{c}16 \\
12.2\end{array}$ & $\begin{array}{c}33 \\
25.2\end{array}$ & $\begin{array}{c}7 \\
5.3\end{array}$ & $\begin{array}{c}61 \\
46.6\end{array}$ & $\begin{array}{c}14 \\
10.7\end{array}$ & 3.18 & 1.03 \\
\hline There exists high formalization of work procedures & $\begin{array}{c}\text { Freq } \\
\%\end{array}$ & $\begin{array}{l}0 \\
0\end{array}$ & $\begin{array}{c}8 \\
6.1\end{array}$ & $\begin{array}{c}7 \\
5.3\end{array}$ & $\begin{array}{c}83 \\
63.4\end{array}$ & $\begin{array}{c}33 \\
25.2\end{array}$ & 4.08 & 0.74 \\
\hline $\begin{array}{l}\text { The manufacturing processes follow standard } \\
\text { practices }\end{array}$ & $\begin{array}{c}\text { Freq } \\
\%\end{array}$ & $\begin{array}{l}0 \\
0\end{array}$ & $\begin{array}{l}0 \\
0\end{array}$ & $\begin{array}{c}3 \\
2.3\end{array}$ & $\begin{array}{c}90 \\
68.7\end{array}$ & $\begin{array}{c}38 \\
29.0\end{array}$ & 4.27 & 0.49 \\
\hline $\begin{array}{l}\text { Communication measurement items } \\
\text { The production system allows easy access }\end{array}$ & $\begin{array}{c}\text { Freq } \\
\%\end{array}$ & $\begin{array}{c}2 \\
1.5\end{array}$ & $\begin{array}{l}11 \\
8.4\end{array}$ & $\begin{array}{c}6 \\
4.6\end{array}$ & $\begin{array}{c}70 \\
53.4\end{array}$ & $\begin{array}{c}42 \\
32.1\end{array}$ & 4.06 & 0.92 \\
\hline $\begin{array}{l}\text { Mechanisms exists to help employees communicate } \\
\text { their innovative ideas }\end{array}$ & $\begin{array}{c}\text { Freq } \\
\%\end{array}$ & $\begin{array}{c}1 \\
0.8\end{array}$ & $\begin{array}{c}18 \\
13.7\end{array}$ & $\begin{array}{c}8 \\
6.1\end{array}$ & $\begin{array}{c}81 \\
61.8\end{array}$ & $\begin{array}{c}23 \\
17.6\end{array}$ & 3.82 & 0.91 \\
\hline $\begin{array}{l}\text { Objectives are communicated to employees on a } \\
\text { one-to-one basis }\end{array}$ & $\begin{array}{c}\text { Freq } \\
\%\end{array}$ & $\begin{array}{c}2 \\
1.5\end{array}$ & $\begin{array}{c}18 \\
13.7\end{array}$ & $\begin{array}{l}12 \\
9.2\end{array}$ & $\begin{array}{c}78 \\
59.5\end{array}$ & $\begin{array}{c}21 \\
16.0\end{array}$ & 3.75 & 0.93 \\
\hline $\begin{array}{l}\text { The information system provides timely necessary } \\
\text { performance objective reports }\end{array}$ & $\begin{array}{c}\text { Freq } \\
\%\end{array}$ & $\begin{array}{c}7 \\
5.3\end{array}$ & $\begin{array}{c}6 \\
4.6\end{array}$ & $\begin{array}{c}9 \\
6.9\end{array}$ & $\begin{array}{c}82 \\
62.6\end{array}$ & $\begin{array}{c}27 \\
20.6\end{array}$ & 3.89 & 0.96 \\
\hline $\begin{array}{l}\text { The management takes timely action on information } \\
\text { from all stake-holders }\end{array}$ & $\begin{array}{c}\text { Freq } \\
\%\end{array}$ & $\begin{array}{c}7 \\
5.3\end{array}$ & $\begin{array}{c}28 \\
21.4\end{array}$ & $\begin{array}{c}4 \\
3.1\end{array}$ & $\begin{array}{c}68 \\
51.9\end{array}$ & $\begin{array}{c}24 \\
18.3\end{array}$ & 3.56 & 1.02 \\
\hline $\begin{array}{l}\text { Formal mechanisms exists to transfer best practices } \\
\text { among various areas of work. } \\
\text { Innovations measurement items }\end{array}$ & $\begin{array}{c}\text { Freq } \\
\%\end{array}$ & $\begin{array}{c}5 \\
3.8\end{array}$ & $\begin{array}{c}18 \\
13.7\end{array}$ & $\begin{array}{c}8 \\
6.1\end{array}$ & $\begin{array}{c}77 \\
58.8\end{array}$ & $\begin{array}{c}23 \\
17.6\end{array}$ & 3.72 & 1.03 \\
\hline $\begin{array}{l}\text { The system and processes are automated by use of } \\
\text { Computer Aided Design }\end{array}$ & $\begin{array}{c}\text { Freq } \\
\%\end{array}$ & $\begin{array}{c}6 \\
4.6\end{array}$ & $\begin{array}{c}24 \\
18.3\end{array}$ & $\begin{array}{c}7 \\
5.3\end{array}$ & $\begin{array}{c}66 \\
50.4\end{array}$ & $\begin{array}{c}28 \\
21.4\end{array}$ & 3.66 & 1.13 \\
\hline $\begin{array}{l}\text { There is continuous improvement of the system to } \\
\text { refine the process }\end{array}$ & $\begin{array}{c}\text { Freq } \\
\%\end{array}$ & $\begin{array}{c}6 \\
4.6\end{array}$ & $\begin{array}{l}13 \\
9.9\end{array}$ & $\begin{array}{l}11 \\
8.4\end{array}$ & $\begin{array}{c}74 \\
56.5\end{array}$ & $\begin{array}{c}27 \\
20.6\end{array}$ & 3.78 & 1.03 \\
\hline $\begin{array}{l}\text { Manufacturing process uses best production method } \\
\text { available }\end{array}$ & $\begin{array}{c}\text { Freq } \\
\%\end{array}$ & $\begin{array}{l}12 \\
9.2\end{array}$ & $\begin{array}{c}29 \\
22.1\end{array}$ & $\begin{array}{c}1 \\
0.8\end{array}$ & $\begin{array}{c}70 \\
53.4\end{array}$ & $\begin{array}{c}19 \\
14.5\end{array}$ & 3.79 & 1.03 \\
\hline $\begin{array}{l}\text { The operations and production process has minimum } \\
\text { possible error }\end{array}$ & $\begin{array}{c}\text { Freq } \\
\%\end{array}$ & $\begin{array}{c}9 \\
6.9\end{array}$ & $\begin{array}{c}25 \\
19.1\end{array}$ & $\begin{array}{c}2 \\
1.5\end{array}$ & $\begin{array}{c}69 \\
52.7\end{array}$ & $\begin{array}{c}26 \\
19.8\end{array}$ & 3.56 & 1.20 \\
\hline
\end{tabular}

Means: $1-1.8=\mathrm{SD}, 1.9-2.7=\mathrm{D}, 2.8-3.3=\mathrm{N}, 3.4-4.2=\mathrm{A}$, Above $4.2=\mathrm{SA}$

Key: $\boldsymbol{S D}=$ Strongly Disagree, $\boldsymbol{D}=$ Disagree, $\boldsymbol{N}=$ Neutral, $\boldsymbol{A}=$ Agree, $\boldsymbol{S} \boldsymbol{A}=$ Strongly Agree 


\subsection{Diagnostic tests}

\subsubsection{Normality test}

In order to analyze the data using inferential statistical techniques, the normality distribution of occurrence for the variable was examined using the Shapiro - Wilk test, presented in table 4.34, whose results revealed that all the measures had a significance index more than the stated $\alpha=0.05$. The test confirms that the deviations from normality are insignificant, an indication that data collected relating to infrastructural choices was approximately normal.

Table 4.34: Tests of Normality for Infrastructural Choices items Infrastructural Choices measurement items

Team empowered to make decisions

Team takes responsibilities to achieve

Work-force has prerequisite competence to perform

Employees' further training is facilitated

policies adopted help achieve set objectives

Workers are involved in setting objectives

Work procedures are formalized

Manufacturing process follow standard practices

Production system allows easy access

Mechanism exist for employees to share ideas

Objectives are communicated on one to one basis

Performance objective reports provided timely

Timely action taken on information

Best practices transferred formally

System is automated by use of CAD

Continuous improvement to refine the process

Manufacturing process uses best method available

Operations process minimizes error

a. Lilliefors Significance Correction

\subsubsection{Reliability test}

All the eighteen (18) measurement items of the infrastructural choices were subjected to reliability test using Cronbach's alpha coefficient as shown in table 4.35 in order to assess construct reliability.

Table 4.35: Reliability Statistics for Infrastructural Choices items

\begin{tabular}{cc}
\hline Cronbach's Alpha & N of Items \\
\hline .915 & 18 \\
\hline
\end{tabular}

As depicted in Table 4.35, the Cronbach's Alpha reliability coefficient for infrastructural choices based on standardized items was 0.915, which is greater than the minimum accepted Cronbach's alpha coefficient of 0.70 (Sekaran, 2003; Katema, 2009). This was considered to be excellently reliable, ensuring sufficient construct reliability. Based on the results, the study conclude that the specific infrastructural choices measurement items were reliable to measure what they were intended to measure, and hence can be used in the subsequent analyses of data in assessing the relationships between the constructs.

The ANOVA table 4.36 indicates that F- Ratio which is a measure of the variation explained by the model and the variation explained by unsystematic factors. Given that the F-ratio is greater than one and significant $(\mathrm{F}(130,17)=16.310, \mathrm{p}<0.05)$, it is an indication that experimental manipulation had some effect above and beyond the effect of individual differences. This implies that there is no chance that the effect occurred by chance.

Table 4.36: ANOVA model for Infrastructural Choices measurement items

\begin{tabular}{|c|c|c|c|c|c|c|}
\hline \multirow{2}{*}{\multicolumn{2}{|c|}{ Between People }} & Sum of Squares & $\mathrm{df}$ & Mean Square & $\mathrm{F}$ & Sig \\
\hline & & 966.240 & 130 & 7.433 & \multirow{5}{*}{16.310} & \multirow{5}{*}{.000} \\
\hline Within & Between Items & 176.090 & 17 & 10.358 & & \\
\hline \multirow{2}{*}{ People } & Residual & 1403.577 & 2210 & .635 & & \\
\hline & Total & 1579.667 & 2227 & .709 & & \\
\hline Total & & 2545.907 & 2357 & 1.080 & & \\
\hline
\end{tabular}

Grand Mean $=3.8024$

\subsection{Exploratory Factor Analysis}

The validity of the model constructs was assessed by exposing the infrastructural choices variable items responses from the questionnaire to exploratory factor analysis, in order to assess the extent to which the observed indicators represents an underlying latent construct fitted with the pre-specified theoretically driven model (Hair, et al., 2005), 
and to identify the least number of factors which can account for the common variance of a set of variables and, to show by how much the co-variation among the observed variables each one accounts for (Field, 2003).

The initial part of the factor extraction process was to determine the linear components within the data set (eigenvectors). Infrastructural decisions with eighteen (18) measurement items were subjected to the factor analysis. Three infrastructural choices components with Eigen values $\geq 1$ were extracted and retained to be loaded in the analysis, as shown in table 4.37.

Table 4.37: Total Variance of Infra structural Choices items Explained

\begin{tabular}{|c|c|c|c|c|c|c|c|c|c|}
\hline \multirow{2}{*}{ 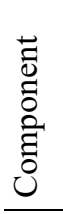 } & \multicolumn{3}{|c|}{ Initial Eigenvalues } & \multicolumn{3}{|c|}{$\begin{array}{l}\text { Extraction Sums of Squared } \\
\text { Loadings }\end{array}$} & \multicolumn{3}{|c|}{$\begin{array}{c}\text { Rotation Sums of Squared } \\
\text { Loadings }\end{array}$} \\
\hline & Total & $\%$ of $\operatorname{Var}$ & Cum \% & Total & $\%$ of $\operatorname{Var}$ & Cum \% & Total & $\%$ of $\operatorname{Var}$ & Cum \% \\
\hline 1 & 4.523 & 50.252 & 50.252 & 4.523 & 50.252 & 50.252 & 2.611 & 29.007 & 29.007 \\
\hline 2 & 1.223 & 13.585 & 63.837 & 1.223 & 13.585 & 63.837 & 2.185 & 24.279 & 53.286 \\
\hline 3 & 1.005 & 11.171 & 75.008 & 1.005 & 11.171 & 75.008 & 1.955 & 21.722 & 75.008 \\
\hline 4 & .643 & 7.144 & 82.151 & & & & & & \\
\hline 5 & .473 & 5.255 & 87.406 & & & & & & \\
\hline 6 & .426 & 4.734 & 92.140 & & & & & & \\
\hline 7 & .292 & 3.244 & 95.384 & & & & & & \\
\hline 8 & .239 & 2.659 & 98.043 & & & & & & \\
\hline 9 & .176 & 1.957 & 100.00 & & & & & & \\
\hline
\end{tabular}

Extraction Method: Principal Component Analysis.

Presented in table 4.37 is a list of eigenvalues associated with each linear component (factor) before extraction, after extraction and after rotation. Before extraction, nine (9) linear factors were identified, while after extraction, three components were extracted, and displayed eigenvalues associated with each factor representing the variance explained by that particular linear component. Accumulatively, the three extracted factors explained approximately 75 percent of the total variance in Infra structural choices. This indicates that the amount of information loss is relatively smaller when the number of indicators was reduced. Meaning that fewer indicators can be used to analyse the data.

However, on an individual basis, it can be deduced that component one accounted for 50.252 percent of the total variance, component two accounted for 13.585 percent, while component three accounted for approximately 11.17 percent of the total variance of structural decisions. Rotation has the effect of optimizing the factor structure and states the relative importance of the factor. However, after extraction and rotation, factor one accounts for approximately 29 percent, factor two accounted for approximately 24.28 percent, while factor three accounted for 21.72 percent of the total variance of infra-structural choices strategies as used by these sugar manufacturing firms in in Kenya.

Table 4.38: Rotated Component Matrix ${ }^{a}$ for Infrastructural Choices items

\begin{tabular}{|c|c|c|c|}
\hline \multirow[t]{2}{*}{ Infrastructural Choices measurement items } & \multicolumn{3}{|c|}{ Component } \\
\hline & Policies & Communication & Workforce \\
\hline Manufacturing process follow standard practices & .808 & & \\
\hline Work procedures are formalized & .794 & & \\
\hline Policies adopted help achieve set objectives & .754 & & \\
\hline Best practices transferred formally & & .802 & \\
\hline Performance objective reports provided timely & & .761 & \\
\hline Timely action taken on information & & .758 & \\
\hline Team empowered to make decisions & & & .885 \\
\hline Team takes responsibilities to achieve & & & .874 \\
\hline
\end{tabular}

Extraction Method: Principal Component Analysis.

Rotation Method: Varimax with Kaiser Normalization.

a. Rotation converged in 5 iterations.

From the rotated component matrix table 4.38, factor one is highly and positively related with "Manufacturing process follow standard practices" measurement item $(0.808)$, followed by "Work procedures are formalized" measurement item with coefficient 0.794 , while the "Policies and procedures adopted help achieve set objectives" item had a coefficient of 0.754 . The second component is highly and positively related with the "Best practices transferred formally" measurement item $(0.802)$, followed by the "Performance objective reports provided timely" 
item (0.761), while the "Timely action taken on information" item had a coefficient of 0.758 . In addition, factor three is highly and positively related with two items, namely: the "Team empowered to make decisions" measurement item with a coefficient of 0.885 followed by the "Team takes responsibilities to achieve" measurement item which had a coefficient of 0.874 .

From the extracted components of the structural decisions in table 4.38, component one is mapped onto Policies, component two is mapped onto Communication, while component three is mapped onto Work - force respectively. The construct items which contributed most to the constructs were thus identified in their order of importance. This implies that the study identified Policies, Communication, as well Work - force respectively, as the important infrastructural choices strategies that these sugar manufacturing firms currently employ.

The study equally generated a reproduced correlations table (Appendix XI) that indicates a principal diagonal of communalities. From the communality table of infrastructural choices, the average of the communalities is given by 0.75 , which is more than the minimum acceptable threshold of 0.70 , an indication that the extracted infrastructural choices measurement items were sufficient enough as a show of accuracy of the identified items of measurement (Field, 2003).

In order to validate construct validity of infrastructural choices, the Kaiser-Meyer-Olkin (KMO) Measure of Sampling Adequacy and Bartlett's Test of Sphericity as a measure of sampling adequacy as shown in table 4.39, indicates that the KMO of sampling adequacy had an index of 0.811 which is greater than the conventional minimum probability value of 0.5 , implying that factor analysis is appropriate for the data set.

In addition, the Bartlett's Test of Sphericity contains an approximated Chi-square of 596.254, with an associated $p$ - value lower than the conventional probability value of 0.05 . It was hence concluded that the factor analysis was appropriate for assessing construct validity of the scale. Consequently, from the Bartlett's Test of Sphericity results, the study rejected the null hypothesis which means that the infrastructural choices variables have a strong association (Hair et al., 2013; Williams et al., 2010; Field, 2003).

Table 4.39: KMO and Bartlett's Test of Sampling Adequacy

\begin{tabular}{|c|c|c|}
\hline Kaiser-Meyer-Olkin Measur & quacy. & .811 \\
\hline & Approx. Chi-Square & 596.254 \\
\hline Bartlett's Test of Sphericity & $\mathrm{df}$ & 36 \\
\hline & Sig. & .000 \\
\hline
\end{tabular}

\subsection{Correlation Analysis}

Correlation statistics measures the extent of association between the ordering of two random variables although; a significant correlation does not necessarily indicate causality but rather a common linkage in a sequence of events. Thus, the current study analyzed the relationships that are inherent among the extracted infra structural choices study items. Consequently, Policies, Communication, and Work - force were the three constructs with the common factors that accounted for common variance of infra structural choices which were extracted and correlated, and whose results are presented in table 4.40 .

Table 4.40: Correlations for Infra structural Choices indicators

\begin{tabular}{llccc}
\hline & & Policy & Communication & Workforce \\
\hline Policy & Pearson Correlation & 1 & & \\
\multirow{2}{*}{ Communication } & Pearson Correlation & $.313^{* *}$ & 1 &. \\
\multirow{2}{*}{ Workforce } & Sig. (2-tailed) & .007 & $.165^{* *}$ & 1 \\
& Pearson Correlation & $.588^{* *}$ & .015 & \\
\hline
\end{tabular}

**. Correlation is significant at the 0.01 level (2-tailed).

Pearson Correlation results in table 4.40 shows that policy is positively weak but significantly related with communication with a Pearson Correlation coefficient $r=0.313, \rho<0.05$. The correlations output equally shows that policy is positively moderate and equally significantly correlated with work force, with a coefficient of $r=$ $0.588, \rho<0.05$. In addition, the study found a weak but significantly positive relationship between communication and work force with $r=0.165, \rho<0.05$. From the correlations table 4.36 all the correlation coefficients are low ( $r$ $=0.165)$ to moderate $(\mathrm{r}=0.588)$, implying that multicollinearity is minimal among the set of identified infra structural construct indicators. This has the advantages of decreasing the probability of committing type II error that can lead to rejecting a good predictor from the model. However, as Field (2003) acknowledges, obtaining less than perfect multicollinearity is practically unavoidable.

On an individual measurement items, the Infra structural choices extracted correlation matrix (Appendix XII) shows the correlations coefficients among the extracted infra structural choices measurement items. The displayed correlation coefficients are between low $(r=0.223)$ to just above moderate $(r=0.782)$, with most of the measurement items recording moderate correlations coefficients. This is a further indication of lack of autocorrelation among the construct measurements items. In general, all the identified infrastructure measurement items as presented in Appendix XII were found to be significant. 


\subsection{Regression Analysis}

The objective of the study was to determine the effect of infrastructural choices on the performance of sugar manufacturing firms in Kenya. The study predicted that the relationship between infrastructural choices and performance is not statistically significant at $5 \%$ level of significance. The resultant infrastructural choices were measured by Policies, Communication, and Work - force. The aggregate mean scores of the extracted infrastructural choices constructs measurement items were regressed against the aggregate mean scores of the extracted performance measures items, and results presented in table 4.41.

Table 4.41: Model Summary ${ }^{b}$ of Infrastructural Choices

\begin{tabular}{|c|c|c|c|c|c|c|c|c|}
\hline \multirow[b]{2}{*}{$\sum_{i}^{\overline{0}}$} & \multirow[t]{2}{*}{$\mathrm{R}$} & \multirow[t]{2}{*}{$\mathrm{R}^{2}$} & \multirow{2}{*}{$\begin{array}{l}\text { Adj. } \\
\mathrm{R}^{2}\end{array}$} & \multirow{2}{*}{$\begin{array}{l}\text { S. E. of the } \\
\text { Estimate }\end{array}$} & \multicolumn{3}{|c|}{ Change Statistics } & \multirow{2}{*}{$\begin{array}{l}\text { Durbin- } \\
\text { Watson }\end{array}$} \\
\hline & & & & & $\mathrm{R}^{2}$ Change & F Change df1 df2 & $\begin{array}{c}\text { Sig. F } \\
\text { Change }\end{array}$ & \\
\hline 1 & $.605^{\mathrm{a}}$ & .366 & .267 & .41246 & .366 & 3.518 & .018 & 1.147 \\
\hline
\end{tabular}

a. Predictors: (Constant), Policies, Communication, Workforce

b. Dependent Variable: Efficiency

The model summary of infrastructural choices in table 4.41 indicated that structural decisions generally accounted for 36.6 percent variation in performance of sugar manufacturing firms $\left(\mathrm{R}^{2}=0.366\right)$. This implies that 63.4 percent variation in performance is accounted for by other variables other than infrastructural choices. In addition, the overall regression results revealed a statistically significant and positive linear relationship between infrastructural choices and performance of sugar manufacturing firms $\left(\mathrm{R}^{2}=0.366, \rho<0.05\right)$.

The value of adjusted $\mathrm{R}^{2}=0.267$ shows how well the model generalizes the prediction. The shrinkage (about $9.9 \%$ ) shows that if the model were derived from the population rather than a sample, it would account for about 9.9 percent less variance in the performance of these sugar manufacturing firms. In addition, the model causes the $\mathrm{R}^{2}$ to change from zero to 0.366 , and this change in the amount of variance explained was found to be insignificant at $5 \%$ level of significance $(\mathrm{F}(1,1)=3.518, \mathrm{p}<0.05)$. Table 4.41 equally shows the Durbin-Watson statistic $(\boldsymbol{d}=$ 1.147), which is in tandem with the rule of the thump as a measure of autocorrelation analysis (Gujarati (2014; Field (2003). Equally included in table 4.41 are the collinearity measures in the data by providing the VIF and Tolerance statistics, which meet the rule of the thump as evidence that the variable is not collinear with other repressors (Both Gujarati, 2004; Field, 2003).

The model coefficient parameters in table 4.42 shows the $\beta$-value which indicates that production policies and procedures significantly contribute to the operations performance of the firm $(\mathrm{t}(1.96)=0.441, \rho<0.05)$. In addition, the study showed that communication equally have a significant contribution to performance $(\mathrm{t}(1.96)=$ $6.256, \rho<0.05)$, while workforce had a significant contribution to performance $(\mathrm{t}(1.96)=4.476, \rho<0.05)$. From the magnitude of the individual $\boldsymbol{t}$-statistics, the study showed that communication has a better contribution to the performance, followed by workforce quality, and then policies.

Table 4.42: Beta Coefficients ${ }^{\mathrm{a}}$ of Infrastructural Choices constructs

\begin{tabular}{|c|c|c|c|c|c|c|c|c|}
\hline \multirow{2}{*}{$\frac{\overline{0}}{8}$} & & \multicolumn{2}{|c|}{$\begin{array}{c}\text { Unstandardized } \\
\text { Coefficients }\end{array}$} & \multirow{2}{*}{$\begin{array}{c}\text { Standardized } \\
\text { Coefficients }\end{array}$} & \multirow[t]{2}{*}{$\mathrm{t}$} & \multirow[t]{2}{*}{ Sig. } & \multicolumn{2}{|c|}{$\begin{array}{l}\text { Collinearity } \\
\text { Statistics }\end{array}$} \\
\hline & & $\mathrm{B}$ & Std. E & & & & Tol & VIF \\
\hline \multirow{4}{*}{1} & (Constant) & 4.696 & 1.385 & & 3.391 & .013 & & \\
\hline & Policies & .472 & 1.070 & .404 & .441 & .036 & .987 & 1.013 \\
\hline & Communication & .488 & .078 & .506 & 6.256 & .044 & .986 & 1.014 \\
\hline & Work-force & .367 & .082 & .390 & 4.476 & .025 & .987 & 1.013 \\
\hline
\end{tabular}

a. Dependent Variable: Efficiency

The hypothesis test criteria was that the null hypothesis $\mathrm{H}_{01}$ should be rejected if $\beta \neq 0$ and $\mathrm{p}$-value $\leq 0.05$ otherwise fail to reject $\mathrm{H}_{01}$ if the $\mathrm{p}$-value $>0.05$. Consequently, the study sought to test the null hypothesis stated thus:

$H_{01}$ : There is no statistical significant effect of Infrastructural Choices on the performance of sugar manufacturing firms in Kenya.

From the model in table 4.42, it can hence be deduced that the linear functional relationship between infrastructural Choices measurements and performance of sugar firms follow the following regression model:

Performance $=\beta_{0}+\beta_{1} \boldsymbol{P}+\beta_{2} \boldsymbol{C}+\beta 3 \boldsymbol{W F}+\varepsilon_{\mathrm{i}}$

$$
=4.696+(0.472 \boldsymbol{P})+(0.488 \boldsymbol{C})+(0.367 \boldsymbol{W F})+\varepsilon_{\mathrm{i}} \ldots \ldots . . . \text { Equation } 4.4
$$

where: $\mathrm{P}=$ Policies, while

$\mathrm{C}=$ Communications

$\mathrm{WF}=$ Work - force

From the above regression study results model, given that all infrastructural choices constructs were 
significant, the study therefore rejected the null hypothesis since $\beta \neq 0$ while the $p$-value $<\alpha$, hence concluded that infrastructural choices have a statistical and significantly positive relationship with performance of sugar manufacturing firms in Kenya, implying that infrastructural choices make a significant and a positive contribution to performance of sugar firms in Kenya.

For this model, the standardized coefficient indicates that as policies, communication, and workforce increase by one standard deviation, the operations performance improves by $0.472,0.472$, and 0.488 standard deviations respectively, holding the effect of all other predictors invariant (Field, 2003). Equally included in table 4.42 are the measures of whether there is collinearity in the data by providing the VIF and Tolerance statistics. From the current model, both the VIF and Tolerance statistics are approximately one, confirming that there were no cases of serial collinearity for the model, and as Gujarati (2004) opines that as a rule of the thump, the closer the tolerance is to one, the greater the evidence that the variable is not collinear with other repressors.

Infrastructural choices have an evolving relationship with operations in the manufacturing industry. Their developments allows the management to make the right investment, bearing in mind the long lags and high manufacturing costs associated with infrastructure development. Conversely, changes in infrastructural choices drives changes in manufacturing. This study results indicate that infrastructural choices have a statistical significance influence on performance $\left(\mathrm{R}^{2}=0.366, \rho<0.05\right)$. This study results confirm a study conclusion by Sciuto and Filho (2013) that infrastructural areas greatly and positively influence various process improvements aimed at increasing productivity and development of robust performance indicators, and a study by Ketema (2015) that found that $74.6 \%$ percent of operations performance is greatly influenced by infrastructural choices $(74.6 \%)$. In addition, the Ketema concluded that structural and infrastructural manufacturing decisions significantly influence manufacturing performance when a firm seeks to achieve quality and delivery priorities.

This underscores the strategic goal of KSB Strategic Plan $(2010$ - 2014) that projected increased performance of sugar manufacturing firms by strengthening institutional policies. Although the study results reveal a significant relationship between policies and workforce on performance, the contribution of communication on performance was however, found to be statistically insignificant, even though both Barnes (2012) and Andersen (2001) outline communication as a core component of infrastructural choice as a performance measurement.

Given that this study results have found operations policies and procedures to be core component of sugar manufacturing process, the study hence adopts the conclusions by Cai et al. (2010) that institutional theory provides the rules and policies that govern the structure and organizational interactions within the decision areas. Moreover, Kraft and Furlong (2007) contents that institutional theory emphasize authoritative guidelines and explains the boundaries of both social behaviour and organization's structure, which is intertwined with a firm's critical resources. Even though a study by Andersen (2001) observes a direct and positive relationship between communication and performance, it offers an interesting insight of the performance association of communication enhancing contribution, and its interactions with different contemporary strategic decision - making approaches. Andersen further highlights large discrepancies and urges a further examination of the mechanics of the alleged performance relationship. The current study results points to the insinuation by Andersen that communication's contribution to performance is mixed and needs a further examination.

But overally, infrastructural choices was found to have a statistical significance effect on performance. This study results confirm the study conclusion by Felipe and Marcia (2014) that manufacturing firms' production strategy is related to the policies and goals, and that infrastructural choices and decisions play a fundamental role in a manufacturing process, and must be aligned to the competitive priorities. Several studies have assessed the contribution of infrastructural choices in the manufacturing process. For instance, Hallgren (2010) argues that infrastructural choices relate to manufacturing systems used to enhance the utilization of structural decisions and are used to control the resources, and further lubricate the decision - making, and control the activities of the operation so that the firm may achieve high levels of productivity. This underscores the significance of infrastructural choices to the manufacturing process.

A study by Slack and Lewis (2012) equally concluded that infrastructural choices strategy areas influence the activities that take place within the operations structure. In addition, Rodri'guez (2014) found a significant and positive relationship between infrastructural practices and policies on overall performance. This further compounds the greater emphasis on manufacturing infrastructure by the firms. Accordingly, the new paradigm reaffirms how manufacturing firms employs to select and control the performance of its structural decisions. In essence, a superior infrastructure allows the firm to extract a better performance.

Although a study by Iyer et al. (2011) argues that a few studies have suggested that there are few infrastructural elements which are receiving attention in the recent times, this study results posits a significant linkage between infrastructural choices and manufacturing performance. This suggests a strong need for infrastructural improvements, support from these sugar manufacturing firms' management in order to improve their performance. 


\section{Summary, Conclusions and Recommendations}

Based on above findings, conclusions were made as a basis of making both policy and research recommendations to the beneficiaries of the study for practice and academia. In addition, areas for further research were identified in the study.

\subsection{Summary}

The specific study objective was to determine the effect of infrastructural choices on the performance of sugar manufacturing firms in Kenya. Infrastructural choices were operationalized by work - force, policies, communication, as well as innovations constructs. The descriptive results revealed that management policies and procedures had the highest mean of 3.92 , followed by work - force with a mean of 3.88 , and communication with 3.81, while innovations had a mean of 3.7.

All the eighteen (18) measurement items of infrastructural choices measurement items were subjected to exploratory factor analysis (EFA) to extract the least number of factors which can account for the common variance of a set of infrastructural choices variable. Upon extraction and rotation, three factors were identified (policies, communication, and workforce), which accumulatively accounted for 75.008 percent of the total variance. The extracted factors had an average communality of 0.75 , which was considered sufficient to show accuracy of the identified items of measurement of infrastructural choices. To validate construct validity of competitive priorities, the KMO of sampling adequacy had an index of 0.811. In addition, Bartlett's Test of Sphericity was performed to determine the appropriateness of using factor analysis (Hair et al., 2013), and was found to have a $\mathrm{p}$ - value less than 0.05 , with an approximated Chi-square of 596.254. It was hence concluded that the factor analysis was appropriate for assessing construct validity of the scale.

Pearson Correlation results showed that policy is weakly but positively related with communication with a Pearson Correlation coefficient $r=0.313, \rho>0.05$. However, this relationship was found to be insignificant. The correlations equally shows that policy is moderately and positively correlated with work force, with a coefficient of $r=0.588, \rho<0.05$. Moreover, this relationship was found to be significant, since. In addition, the study found a weak but significantly positive relationship between communication and work force with $\mathrm{r}=0.165, \rho<0.05$.

The study findings revealed a positive and significant statistical effect of infrastructural choices on performance of sugar manufacturing firms in Kenya $\left(\mathrm{R}^{2}=0.366, \rho<0.05\right)$. At individual level, the study found that policies have 29.5 percent effect on performance $\left(R^{2}=0.295, \rho<0.05\right)$, communications had a 15.3 percent effect on performance $\left(\mathrm{R}^{2}=0.153, \rho<0.05\right)$, while workforce had a 13.1 percent effect on performance $\left(\mathrm{R}^{2}=\right.$ $0.131, \rho<0.05)$. Therefore, at $5 \%$ level of significance, the study rejected the null hypothesis and hence concluded that infrastructural choices have statistical significant effect on performance of sugar manufacturing firms in Kenya.

\subsection{Conclusion}

Infrastructural choices, which have been considered as the "software" of the firm have a significant effect on performance of sugar manufacturing firms in Kenya. This implies that these sugar manufacturing firms need to continuously improve and innovate in order to improve their performance

\subsection{Recommendation}

The primary recommendation is that the manufacturing firms should give due attention to the infrastructural choices in their areas of operations as regards the policies, communication, as well as qualities of the workforce. In order to improve their manufacturing performance, sugar manufacturing firms should encourage employees' personal growth and development, communication, as well as to improve internal policies regarding the acquisition and utilization of infrastructural choices at the operations areas. Moreover, these sugar manufacturing firms were found to have identified routines that are embedded in their processes, systems, and practices, which are used as critical drivers to superior performance.

\subsection{Proposed Areas for Further Research}

The study results are as a result of explored infrastructural factors through EFA. Several items of the study variables were dropped from the analysis. There is need for further research on the constructs to critically examine their significance. Further, contrary to literature, the study found an insignificant contribution of structural decisions to performance. Researchers are encouraged to explore these variables so as to test their significance to manufacturing system, and their extent of their contribution. Moreover, the whole manufacturing sector would have benefitted if the study is done on the whole manufacturing industry.

\section{REFRENCES}

Abdulkareem, A. A. (2010). Competitive Priorities and Competitive Advantage in Jordanian Manufacturing. University of Huddersfield, Emerging Markets Research Group. Huddersfield, UK.: University of 
Huddersfield.

Abdulkareem, S. A. (2013, March). Competitive Priorities and Competitive Advantage in Jordan Manufacturing. Journal of Service Science and Management, 6, 69 - 79.

Allen, I. E. (2007, July). Likert Scales and Data Analyses. Retrieved April. 6th, 2016, from www.qualityprogress.com: analyses.html

Amenta, E. \&. (2010). Institutional Theory. In E. a. Amenta, \& T. L. Kevin (Ed.), The Handbook of Politics: State and Civil Society in Global (pp. 15 - 35). New York.: Springer.

Andersen, T. J. (2001, May.). Information Technology, Strategic Decision Making Approaches and Organization Performance in Different Industrial Settings. Journal of Strategic Information Systems. , 10, 101 - 119.

Barnes, S. (2012). Operations, Strategy and Operations Strategy. In S. Barnes, Operations Management (pp. 21 43). CENGAGE.

Bhargava, R. K. (2014, May.). Education and Work-Experience - Influence on the Performance. Journal of Business and Management., 16(5), 104-110.

Boyer, K. \&. (2002, Pring). Competitive Priorities: Investigating the Need for Trade-Offs in Operations Strategy. Production and Operations Management., 11(1), 9 - 19.

Boyer, K. K. (2015, May 5th). Operations Strategy Research in the POMS Journal. Production and operations Management Society., 14(4), 442 - 449.

Brown, S. \&. (2016). Capabilities And Competencies - Toward Strategic Resonance Between Operations And Strategy Processes Within Firms. (B. Square, Ed.) International Journal of Operations Management., 7,1 30 .

Brown, T. (2006). Confirmatory Factor Analysis for Applied Research. (D. A. Kenny, Ed.) New York., London: The Guilford Press.

Cooper, D. R. (2013). Business Research Methods (12th ed.). New Delhi.: Irwin: Mc Graw Hill.

Creswell, J. W. (2006). Research Designs: Quantitative, Qualitative and Mixed Method Approaches. (2nd ed.). (C. D. Laughton, Ed.) London, California, United Kingdom: Sage Publications, Inc.

Czarnikow. (2013). Africa Sugar Industry: A Rising Star. International Sugar Journal, 1 - 8.

Dung, N. V. (2012). An Institution - Based View of the Competitive Advantage of Firms in Emerging and Transition Economies: The case of Vietnamese Exporters. PhD. Dissertation, Louvain School of Management.

Field, A. (2003). Discovering Statistics Using SPSS For Windows. (B. Wright, Ed.) London: SAGE Publications.

Gachene, C. K. (2012). Browsing The Sugar Research Institute. East African agricultural and forestry journal., $78(1 \& 2), 23-31$

Gagnon, S. (2009). Resource-based competition and the new operations strategy. . Intemadonai Joumal of Operations and Production Mnagement., 19(2), 125 - 138.

Gong, Y. (2013). Global Operations Strategy: Fundamentals and Practice. Springer Texts in Business and Economics, . Ecully., France.: Springer.

Gujarati, D. N. (2014). Basic Econometrics. (4Th. ed.). McGraw-Hill.

Hair, J. F. (2010). Multivariate Data Analysis . (6th ed.). Upper Saddle River, NJ: Prentice Hall.

Hallgren, M. (2010, Spring 2). Manufacturing Strategy, Capabilities and Performance. (UniTryck, Ed.) Linköping Studies in Science and Technology, 1(1), 1 - 33.

Hayes, R. H. (2005, July). Manufacturing Strategy: At The Intersection of Two Paradigm Shifts. Production and Operations Management Society., 5(1), 1 - 17.

Helkiö, P. (2008). International Investigation of Manufacturing Flexibility: Strategies, Contingencies and Antecedents. Industrial Engeneering and Management., 40 - 67.

Iyer, A. K. (2011). Indian Manufacturing - Strategic and Operational Decisions and Business Performance. Working Paper no. 338, Karnnert.: Indian Institute of Management Bangalore.

Kasie, F. M. (2013). The impact of multi-criteria performance measurement on business Performance Improvement. Journal of Industrial Engineering and Management (JIEM)., 6(2), 595-625.

Ketema, G. B. (2015). Drivers of Manufacturing Performance in Medium and Large Scale Firms in Ethiopia (Evidence from Addis Ababa and its Periphery). UNISA, Business Leadership. UNISA.

Kombo, D. \&. (2009). Proposal and Thesis Writing: An Introduction. Nairobi, Kenya.: Paulines Publications Africa.

Kothari, C. R. (2010). Research Methodology: Methods and Techniques. (2nd ed.). New Delhi, Jaipur., India: New Age International (P) Ltd.

Kraft, M. E. (2007). Public Policies: Politics, Analysis, and Alternatives. (2nd ed.). London, Washington, D.C: Eurospan.

Littlefield, M. \& Shah, M. (2008). Manufacturing Operations Management: The Next Generation of Manufacturing Systems. Harte Hanks Company. Aberdeen Group.

Luger, M. B. (2013, October). Infrastructure and manufacturing: Their Evolving Relationship. Foresight, 
Government Office for Science.(20), 1 - 34.

Malaba, P. N. (2014, November.). INFLUENCE OF GREEN SUPPLY CHAIN MANAGEMENT STRATEGY ON PROCUREMENT PERFORMANCE OF SUGAR INDUSTRY IN KENYA. International Journal of Economics, Commerce and Management, 2(11), 1 - 24.

Malonza, A. M. (2014). Lean Manufacturing and Operational Performance of Mumias Sugar Company Limited. $50-63$.

Mbalwa, P. N. (2014., November.). Effect of Corporate Governance on Performance of Sugar Manufacturing Firms in Kenya: A Case of Sugar Manufacturing Firms in Western Kenya. Journal of Business and Management, 16(11), $86-112$.

Moller, M. J. (2013). Managing Buyer - Supplier Relationshipsand Inter- Orgaizational Competence Development. Journal of Management, 14(4), 369-379.

Mutunga, S. L. (2014, November). Generic Strategies. International Journal of Business and Management Review, 2(6), 1-15.

Mutunga, S. L. (2014, May). INNOVATIVE ADAPTATION AND OPERATIONAL EFFICIENCY ON SUSTAINABLE COMPETITIVE ADVANTAGE OF FOOD AND BEVERAGE FIRMS IN KENYA. European Journal of Business and Innovation Research., 2(2), 32 - 50.

Nassiuma, D. K. (2000). Survey Sampling: Theory and Methods. Egerton University Press.

Ngumi, P. M. (2013). Effect of Bank Innovations on Financial performance of Commercial Banks in Kenya. Jomo Kenyatta University of Agriculture and Technology. Unpublished PhD. Thesis., Nairobi.

Onen, D. \&. (2009). Ageneral Guide to Writing Research Proposal and Report: A Handbook for Beginning Researchers. (2 ed.). Nairobi., Kenya: JKF.

Raheman, A. Q. (2010). Efficiency Dynamics of Sugar Industry of Pakistan. The Pakistan Development Review, $43(4), 1-25$.

Rodri'guez, T. F. (2014). The Structural and InfraStructural Decisions of Operations Management in the hotel sector and their impact on Organizational Performance. 1(2), 1 - 16.

Rodrigues, H. S. (2008). Critical Success Factors and Core Competencies. Journal of Operations and Management., 364 - 366.

Rolstadas, A. (2012). Manufacturing Strategies Created Through Decisions. Manufacturing Outsourcing, 87 - 91.

Schroeder, R. (2011). A resource-based view of manufacturing strategy and the relationship to manufacturing performance. Strategic Management Journal, 105 - 117.

Sciuto, J. M. (2013). Operation Strategy and Lean Manufacturing: A Study in A Metallurgical Company. International Conference on Industrial Engeneering and Operations Management. (pp. 1 - 8). Valladolid, Spain.: ICIEOM.

Slack, N. \&. (2009). Operations Strategy. (Second ed.). (A. Slack, Ed.) Delhi, India: Dorling Kindersley PVT Ltd.

Slack, N. \&. (2011). Operations Strategy. (3rd. ed.). Prentice Hall.

Söderbom, M. (2011). Constraints and Opportunities in Kenyan Manufacturing: Report on the Kenyan Manufacturing Enterprise Survey. University of Oxford, Department of Economics. Centre for the Study of African Economies.

Suzana, N. R. (2014). Competitive Priorities od Manufacturing firms in the Carbbean. IOSR Journal of Business and Management, 16(10), 72 - 82.

Tyler, G. (2013). The African Sugar Industry: A frastrated Success Story. International Sugar Journal(6), 1 - 8.

Wamalwa, M. S. (2014, May). Effects of Lean Manufacturing technology strategy Implimentation on Factory Time Efficiency, a case of Mumias Sugar Company Limited in Kakamega County, Kenya. International Journal of Business and Management Invention., 3(5), 1 - 10.

Wheelright, S. C. (2001, May - June). Reflecting Corporate Strategy in Manufacturing Decisions. Harvard Business Review, 57 - 66.

Wheelwright, S. C. (2001). Reflecting Corporate Strategy in Manufacturing Strategy. Business Horizons, 57 - 67.

Zaim, H. Y. (2013, December.). Analyzing the Individual Effect of Competencies on Performance: A field Study in Service Industry in Pakistan. Journal of Global Strategic Management, 7(2), 67 - 77. 